\title{
POPULATION STATUS AND THREATS OF PHAEDYMA ASPASIA KATHMANDIA FUJIOKA 1970 (LEPIDOPTERA: NYMPHALIDAE), AN ENDEMIC SUBSPECIES OF BUTTERFLY IN GODAVARI FOREST OF CENTRAL NEPAL
}

\author{
B. Khanal', M.K. Chalise ${ }^{2}$ and G.S. Solanki ${ }^{3}$
}

\section{ABSTRACT}

This study was designed specifically to assess the population status and prevailing threats of Phaedyma aspasia kathmandia an endangered and endemic subspecies of butterfly confined to a very narrow range at 1600-1800 m of elevation in Godavari forest of Lalitpur district of central Nepal. This study revealed the occurrence of only 11 individuals of this species during the study period on July, 2011 and May to July, 2012. The underlying threat to this butterfly is the establishment of the marble quarry around its habitat area. Habitat shrinkage of this butterfly has been noticed due to construction of road at the expense of pristine forest of this part.

Keywords: endangered, endemic, subspecies, butterfly, habitat

\section{INTRODUCTION}

For the last two decades, the operation of marble mining imposed a serious impact on the habitats of many butterflies occurring in this area. The habitat of Great Hockey Stick Sailor (Phaedyma aspasia kathmandia) an endemic subspecies of Nymphalid butterfly which is confined to the elevation of $1600-1800 \mathrm{~m}$ at the area of marble quarry is impacted most as shown by current study. This is the target species of this work which has not been reported elsewhere except this narrow range of the Godavari forest. This butterfly appears for a brief period of May to June in the shady forest parts near the quarry site. Similarly, Euthalia duda, an endangered species also occurs in this part with none of its report so far been made from other parts of the country.

\section{STUDY AREA}

Godavari is located approximately 10 kilometer south to Kathmandu city within the geographical stand of $27^{\circ} 35^{\prime} \mathrm{N}$ to $85^{\circ} 24^{\prime} \mathrm{E}$. The pristine ecosystem of Godavari-Phulchoki still retains diverse and significant habitats for many rare and endangered species of them some are restricted to this part only. Besides the Royal Botanical Garden, Godavari is also famous for rare and diverse butterflies, which can be seen at every minute of walk at the forest trail and garden areas. Godavari Kunda is the next attraction of this part which is actually a spring with high religious value.

Two types of forests are predominant in this district which includes coniferous evergreen and deciduous mixed forests. The former forest can be seen above $2134 \mathrm{~m}$ where vegetations like Pinus wallichiana, Rhododendron arboreum, Alnus nepalensis, Quercus semicarpifolia 
Arundinaria sp., Berberis sp. etc are found. Quercus lamellosa-Laurus (laurels) occurs in the middle of Phulchowki Mountain. Factors responsible to influence the climate of GodavariPhulchoki region are the floor area and Mahabharat mountain range besides the direction of the wind in summer and winter seasons. Godavari forest below the Phulchoki mountain $(2734 \mathrm{~m}$ of elevation) includes prominent vegetations like Castanopsis indica, Myrica esculenta, Prunus cerasoides, Alnus nepalensis, Schima wallichii, Quercus semicarpifolia and Rhododendron arboreum at the Phulchoki mountain side.

The temperature ranges from $10^{\circ}$ to $14^{\circ} \mathrm{C}$ during winter and $15^{\circ}$ to $30^{\circ} \mathrm{C}$ in summer. Snow fall occurs on the hills in winter and heavy rainfall occurs in summer. Phulchoki Mountain is the notable place for snowfall during extreme winter.
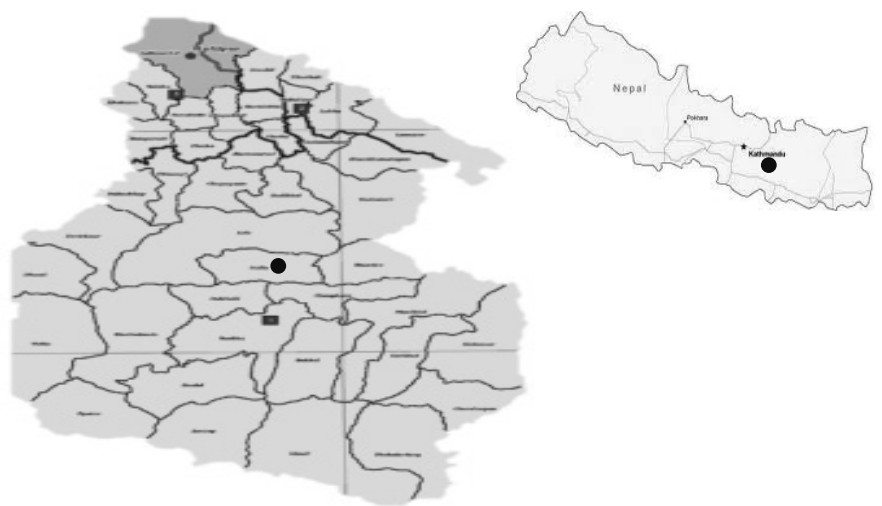

Figure 1. Location of study area.

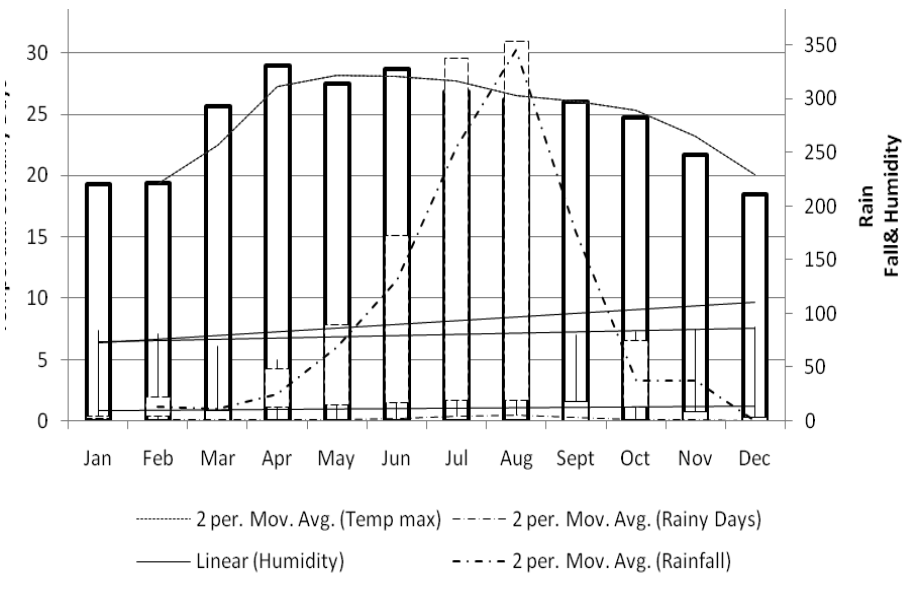

Figure 2. Climate pattern of Lalitpur district. 


\section{MATERIALS AND METHODS}

Godavari forest at the southern end of Kathmandu Valley has many preferable habitats to shelter diverse species of butterflies of various status categories

Phaedyma aspasia kathmandia (Great Hockey Stick Sailor) which is the target species of this study was explored for various periods in July end of 2011 and May end to July end of 2012. This butterfly appeared only for a brief period of two months from the end of May to July end every year. This study was made by direct observation and adopting capture and release method. Field identification was done consulting Khanal and Smith (1997) and Smith (1989). To bring accuracy in field data, altitude, time date and locality of every observed specimen was recorded. Vegetation components occurring in and around the habitat and ecosystem of the target species were analyzed and identified properly.

\section{RESULTS AND DISCUSSION}

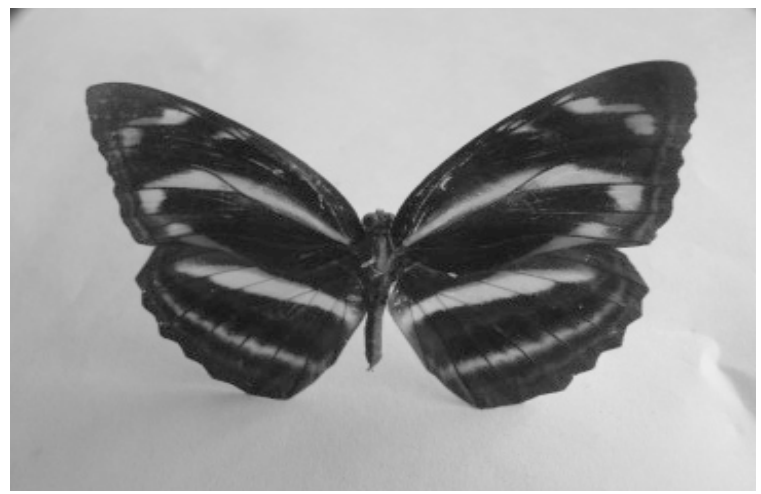

Plate 1. Phaedyma aspasia kathmandia.

Phaedyma aspasia kathmandia has its upper side black with markings dark yellow, forewing with prominent hockey stick like streaks (Fujioka 1970). Total records of 3 individuals were made at the end of July (within 10 days), 2011 which is the end season for its appearance. Of the total records, one of the specimens was in damaged form. This butterfly was found mostly attracted to Alnus nepalensis for its visiting plant. Other species of plants found in its habitats are Quercus semicarpifolia, Schima wallichii and Rhododendron arboreum. Eupatorium adenophorum and Artimisia vulgare are widely spread shrub species around its habitat areas.

At the end of May to end of July 2012, a total of eight specimens were recorded. These specimens were confined to the elevation of $1600-1800 \mathrm{~m}$, mostly in shady forest habitat where least human disturbances occurred. 
J. Nat. Hist. Mus. Vol. 27, 2013

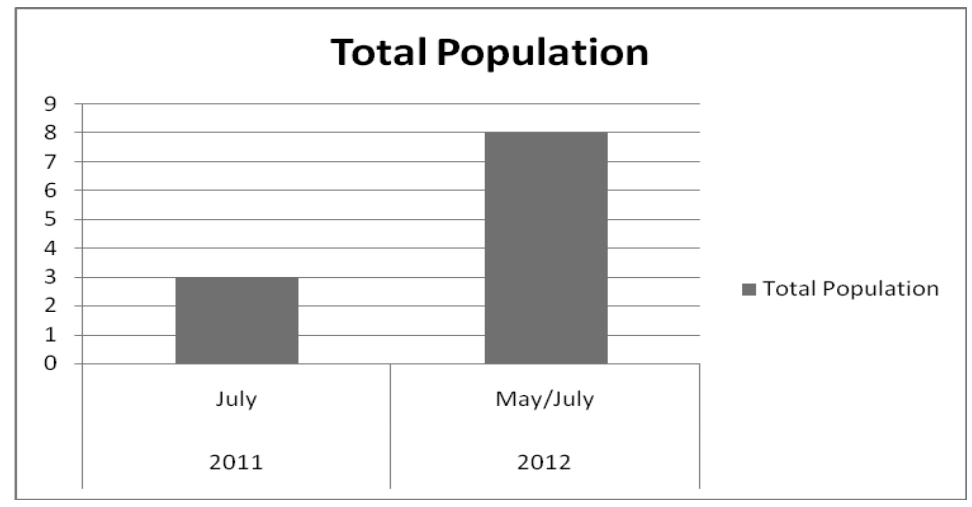

Figure 3. Representation of the recorded population in 2011 and 2012.

Natural History Museum in Kathmandu represents two specimens of the target species placed in its reference collection. The data tag indicates that the collection was made in 1980 from the same locality where this study was conducted.

\section{Conservation Issue}

The following factors have major role to impose impact on survival of Phaedyma aspasia kathmandia in Godavari forest of central Nepal.

Mining: The marble mining nearby the habitat has left impact on the target species. The habitat of the target species which occurred at the proper site of the marble quarry has been destroyed completely under irreparable state in present context. According to Mishra and Reddy (2009), mining is not only a direct, but also has an underlying cause of forest loss and degradation. It causes negative impact on wildlife, river systems, tribal livelihood, tourism and climate. Though mining needs to be continued in a sustainable manner, critical ecosystems like forests should not be sacrificed for short term gain.

Transportation: The non-gravelled road constructed to transport marble slabs, stones and essential quarry related equipments to and from the operation site has narrowed the habitat area of the target species.

Butterflies are sensitive insects which are prone to alter their status even with a slight change in environmental factors. Comparing a decade back study, many species are changing their status from common to the rare states. The impact observed is mainly by anthropogenic cause and is very deteriorating and challenging as well and put a question for the survival of butterflies in this country. Eliot (1969) described Phaedyma aspasia falda from Bhutan and Assam. According to his description the markings of the upperside are suffused with white in subspecies falda and the other superficial characteristics mentioned by Eliot (1969) seemed to be different.

Gupta (2005) stated that the increasing pressure of human population has adversely affected the population of many butterflies and their diversity as well. Man's encroachment on the natural habitats of butterflies has led to clearing of forests for human settlements and their requirements of 
industrialization, urbanization, hydroelectric projects, etc. Consequently, with the shrinkage of their habitats there was decline in their diversity and populations and disturbed the food chain equilibrium. With the latter aspect and other threats to their survival, some species namely Teinopalpus imperialis, Achillides krishna, Neptis manasa, Neptis nycteus etc. have become very rare and endangered. This also can be exemplified with the target Phaedyma aspasia kathmandia.

The increasing deforestation leading to habitat loss has been considered seriously for the decline of butterfly species. Many species which were common in the past are scarce these days. The government policy for conservation (except protected area system) has not been implemented effectively. Basic requirement for conservation is the awareness and education which needs effectiveness in its implementation.

\section{ACKNOWLEDGEMENTS}

The generous support made by the reputed Mohamed bin Zayed Species Conservation Fund, Dubai, helped us to reveal out the conservation status of the target species. So the first author would like to render his sincere thanks for this significant funding. Senior Botanist and Associate Professor at Natural History Museum Dr. Nirmala Pradhan is highly acknowledged for her kind help in identifying some of the plant specimens of Godavari. Mr. Madan Krishna Shrestha (Zoologist), Ms. Suprabha Shrestha (Botanist) and Ms. Sanam Prajapati (Botanist) are highly acknowledged for their help in the field. Our thanks are due to conservation officials, environmentalists, environmental lawyers, community leaders, local inhabitants and all those whose suggestions to conserve butterflies in this region is highly appreciable.

\section{REFERENCES}

Eliot, J.N., 1969. An analysis of the Eurasian and Australian Neptini. The Bull. Brit. Muse., Supp.15. Fujioka, T., 1970. Butterflies collected by the Lepidopterological Research expedition to Nepal Himalaya, 1963. Spec.Bull. Lep.Soc. Jap. Lepidopterological Society, 36, Japan.

Gupta, I.J., 2005. Butterflies of India Red Data Book Part 2, Zoological Survey of India, Kolkata, pp 312, $\mathbf{x v + 5 3 6 . ~}$

Khanal, B. and Smith, C., 1997. Butterflies of Kathmandu Valley, Tecpass Press, Bangkok, Thailand. Mishra, P.P., and M.G. Reddy, 2009. Mining in forest areas- problems, causes and concerns: A review. RULNR-CEEULNRSS, Working paper series No.1, July, pp 29.

Smith, C., 1989. Butterflies of Nepal. Majupuria Publication, Kathmandu, Nepal, 350 p.

\section{AUTHOR'S ADDRESS}

Bhaiya Khanal'

Natural History Museum, Tribhuvan University, Swayambhu, Kathmandu, Nepal (email: baya2000@live.com)

Mukesh Kumar Chalise ${ }^{2}$

Central Department of Zoology, Tribhuvan University, Kirtipur, Kathmandu, Nepal,

\section{Ghana Shyam Solanki ${ }^{3}$}

Department of Zoology, Mizoram University, Mizoram, India 